\title{
PERILAKU MENCUCI TANGAN MAHASISWA BERASRAMA DAN DERAJAT KEBERSIHAN TANGAN: INDIKASI PROGRAM PENCEGAHAN INFEKSI FEKAL-ORAL
}

\author{
HIDDER BEHAVIOR BEHAVIOR AND STUDENTS STUDENTS HIDDEN DEGREES: \\ PRECAUTION INDICATION OF FECAL-ORAL INFECTION PREVENTION
}

\author{
Yohana Fresha Rihi Hina', Samuel Simanjuntak ${ }^{2}$, Idauli Simbolon ${ }^{3}$ \\ Fakultas IImu Keperawatan Universitas Advent Indonesia \\ Email: yanarh01@gmail.com
}

\begin{abstract}
ABSTRAK
Peneliti melakukan pengamatan terhadap pola hidup bersih sehat mahasiswa Universitas Advent Indonesia yang tinggal di asrama secara berkoloni yang selalu berhubungan satu dengan yang lain sehingga menjadi rentan terhadap penularan penyakit. Tujuan dalam penelitian ini adalah untuk mengetahui perilaku cuci tangan dan kebersihan tangan mahasiswa berasrama. Metode yang digunakan dalam penelitian ini adalah pra eksperimental dengan pre-test dan post-test design dengan uji paired t-test dimana jumlah bakteri ditangan responden diukur sebelum dan sesudah mencuci tangan setelah defekasi, kemudian diberi penyuluhan tentang cuci tangan dan infeksi fekal oral. Responden dalam penelitian ini adalah 20 orang mahasiswi yang dipilih secara accidental sampling. Hasil dari penelitian ini menunjukan mahasiswa berasrama berasrama yang bertempat tinggal di Ruth Hall lantai 2 jarang melakukan praktik cuci tangan. Jumlah bakteri yang tertinggal setelah defekasi adalah $1.89 \mathrm{koloni} / \mathrm{cm} 2$ sebelum cuci tangan, dan $0.89 \mathrm{koloni} / \mathrm{cm} 2$ setelah cuci tangan. Gangguan fekal oral yang dialami responden adalah diare dengan presentasi $55 \%$ atau dialami oleh 11 orang responden. Frekuensi diare terbanyak adalah $1 \times(30 \%), 2 \times(15 \%), 3 \times(10 \%)$, dan tidak pernah (45\%). Ada perbedaan yang signifikan antara jumlah bakteri pada tangan sebelum pencucian dengan sabun dengan jumlah bakteri pada tangan setelah pencucian dengan sabun. Promosi kesehatan untuk menggalakkan gerakan cuci tangan sebagai pencegahan penyakit menular dalam komunitas, dengan karakteristik hidup berasrama (koloni) dinilai sangat perlu dilakukan.
\end{abstract}

Kata kunci: Cuci Tangan, Infeksi Fekal Oral

\begin{abstract}
Conducted observations of clean healthy lifestyle of students who live in dormitories of Universitas Advent Indonesia found that they are in touch with each other so that it becomes susceptible to disease transmission as it is true to the collony living. The purpose of this research is to know the practice of handwashing and the degree of hand hygiene of students in boarding school. The method used in this study is a pre experimental with pre-test and post-test design with paired t-test where the number of bacteria in the hands of the respondents was measured before and after washing hands after defecation, then followed by health education about hand washing and fecal-oral infection. Respondents in this study were 20 female students selected by accidental sampling. The results of this study indicate that the boarding students who reside in Ruth Hall 2nd floor rarely do the hand washing practices. The mean number of bacteria after defecation is 1.89 colonies cm2 prior to washing hands, and 0.89 colonies/cm2 after hand washing. The fecal-oral disorders experienced by respondents is diarrhea which experienced by $55 \%$ or 11 respondents. The incidence of diarrhea reported is $1 x$ (experineced by 30\%), $2 x$ (experineced by 15\%), 3x (experienced by $10 \%$ ), and never (45\%). There are significant differences between the number of bacteria on hands before washing with soap by the number of bacteria on the hands after washing with soap. Health promotion to promote hand washing movement as prevention of infectious diseases in the community, with the characteristics of boarding life (colonies) is considered very necessary.
\end{abstract}

Keywords: Hand Washing, Faecal Oral Infection
JURNAL

SKOLASTIK KEPERAWATAN

Vol. 2, No.2

Juli - Desember 2016

ISSN: $2443-0935$

E-ISSN: 2443 - 1699 


\section{PENDAHULUAN}

Mencuci tangan merupakan kegiatan yang sangat ringan untuk dilakukan, namun tindakan ini dianggap sebagian besar orang adalah suatu hal yang sepele, sehingga seringkali diabaikan. Walaupun mencuci tangan tidak membutuhkan biaya besar, akan tapi memiliki efek dan manfaat yang sangat besar bagi kesehatan. James, Baker, Swain (2008) mengatakan mencuci tangan merupakan rutinitas yang murah dan penting dalam prosedur pengontrolan infeksi dan merupakan metode terbaik untuk mencegah transmisi mikroorganisme.

Nadesul (2006) mengatakan dengan menerapkan cuci tangan sebagai kebiasaan sehari-hari maka tubuh akan terbebas dari berbagai penyakit, khususnya penyakit umum yang sering terjadi yaitu thypoid, hepatits, diare. World Health Organization (WHO, 2009) secara global 4 miliar kasus diare terjadi dan 2.2 juta orang diantaranya meninggal, untuk thypoid diperkirakan kejadiannya 2.16 juta dengan jumlah kematian sebesar 216.000 orang, sedangkan hepatitis setiap tahunnya 20 juta orang terinfeksi dengan 3 juta menunjukkan gejala dan 56.000 orang meninggal.

Data penelitian dari Riset Kesehatan Dasar (Riskesdas) tahun 2013 menyatakan di Indonesia penyakit diare pada semua umur kasusnya $21.8 \%$, Data penelitian dari

Riskesdas pada tahun 2013 menyatakan masyarakat Indonesia berumur 10 tahun ke atas yang menerapkan cuci tangan yang benar adalah $47 \%$ sedangkan penduduk di Jawa Barat 43\%, yang dianggap benar bila cuci tangan pakai sabun sebelum menyiapkan makanan, setiap kali tangan kotor (memegang uang, binatang dan berkebun), setelah buang air besar, setelah menceboki bayi/anak, setelah menggunakan pestisida/insektisida, sebelum menyusui bayi, sebelum makan, dan setelah memegang unggas/binatang.

Infeksi fekal-oral merupakan salah satu faktor penularan penyakit yang tidak diperhatikan akibat yang ditimbulkan, sehingga tidak banyak yang melakukan pencegahan untuk hal tersebut. Pencegahan infeksi fekal-oral sangat mudah untuk dilakukan yaitu dengan mencuci tangan. Dinkes Jabar (2015) menuliskan tangan yang bersentuhan langsung dengan kotoran manusia dan binatang, ataupun cairan tubuh, dan makanan/minuman yang terkontaminasi saat tidak dicuci dengan sabun dapat memindahkan bakteri, virus, dan parasit pada orang lain.

Health Education And

Training (HEAT, 2013) menjelaskan Infeksi fekal-oral merupakan penyebaran agen infeksi (virus, bakteri, dan parasit) yang terdapat pada feses dan memasuki tubuh melalui mulut dimana penularannya melalui tangan, makanan atau air, serta benda yang telah terkontaminasi. Cara untuk mencegah transmisi fekal-oral adalah dengan mencuci tangan menggunakan sabun dan air setelah menggunakan toilet, setelah mengolah tanah, sebelum menyiapkan makanan. Peneliti melakukan pengamatan terhadap pola hidup bersih sehat mahasiswa Universitas Advent Indonesia yang tinggal di asrama secara berkoloni yang selalu berhubungan satu dengan yang lain sehingga menjadi rentan terhadap penularan penyakit sehingga tertarik untuk melakukan penelitian dengan judul: "PERILAKU MENCUCI TANGAN MAHASISWA BERASRAMA DAN DERAJAT KEBERSIHAN TANGAN: INDIKASI PROGRAM PENCEGAHAN INFEKSI FEKALORAL"

\section{BAHAN DAN METODE}

Alat yang digunakan dalam penelitian ini adalah:

1) Incubator untuk menyimpan media biakan bakteri.

2) Media agar untuk membiakan bakteri.

3) Leaflet sebagai media dalam penyuluhan mencuci tangan. 
Bahan yang digunakan dalam penelitian ini adalah:

1) Sabun untuk mencuci tangan responden setelah defekasi.

2) Bakteri pada tangan responden setelah defekasi. Pengukuran jumlah bakteri dilakukan sebanyak dua kali, yaitu sebelum responden mencuci tangan setelah defekasi dan sesudah responden mencuci tangan setelah defekasi.

\section{HASIL}

Hasil yang dianalisa dalam penelitian ini adalah:

1. Mahasiswa berasrama berasrama yang bertempat tinggal di Ruth Hall lantai 2 jarang melakukan praktik cuci tangan.

2. Gangguan fekal oral yang dialami responden adalah diare dengan presentasi 55\% atau dialami oleh 11 orang responden. Frekuensi diare terbanyak adalah 1x (30\%), 2x $(15 \%)$, 3x (10\%), dan tidak pernah (45\%).

3. Jumlah bakteri yang tertinggal setelah defekasi saat ini adalah 1.89 koloni/cm2.

4. Jumlah bakteri yang tertinggal setelah mencuci tangan adalah 0.89 koloni/cm2 5. Ada perbedaan jumlah bakteri praktik mencuci tangan setelah defekasi saat ini dengan jumlah bakteri mencuci tangan setelah menggunakan sabun.

Tabel 4.2 Perilaku cuci tangan saat ini

\begin{tabular}{|c|c|c|c|c|c|}
\hline & & Frequency & Percent & Valid Percent & Cumulative Percent \\
\hline \multirow[t]{3}{*}{ Valid } & Tidak pernah & 9 & 45.0 & 45.0 & 45.0 \\
\hline & Diare & 11 & 55.0 & 55.0 & 95.0 \\
\hline & Total & 20 & 100.0 & 100.0 & \\
\hline
\end{tabular}

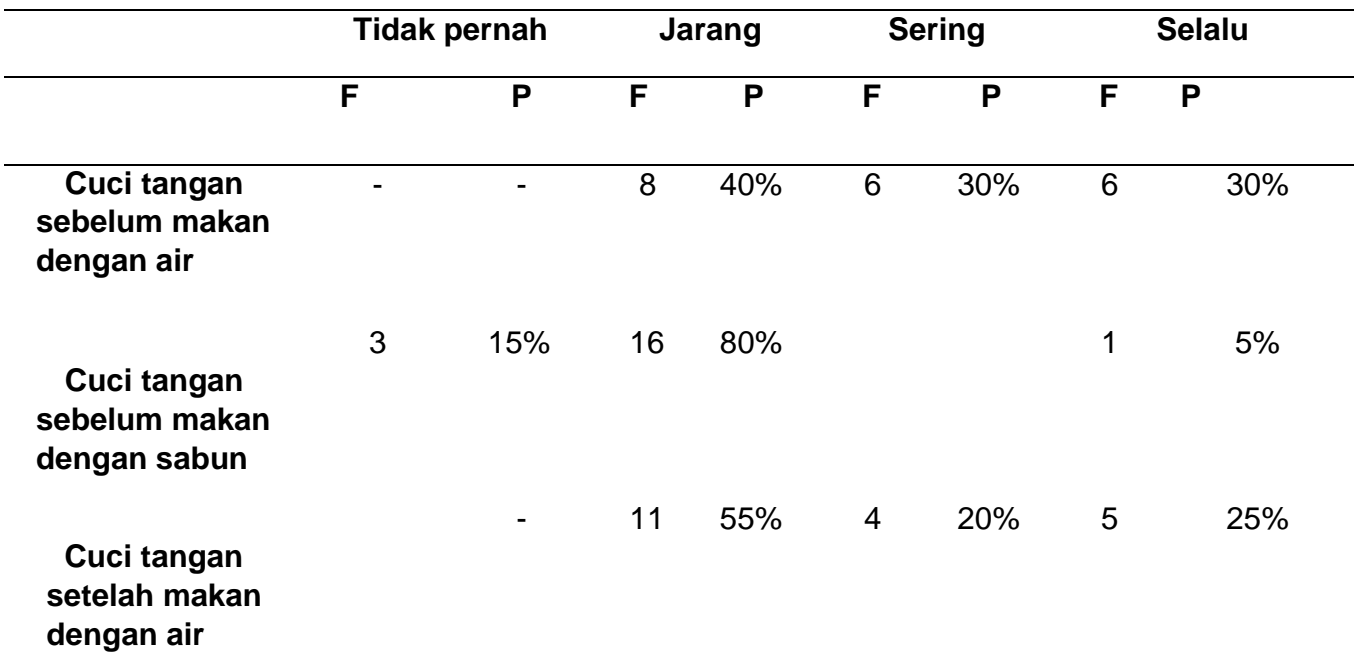


Cuci tangan setelah makan dengan sabun

Cuci tangan setelah BAB dengan air

Cuci tangan setelah BAB dengan sabun

Cuci tangan setelah BAK dengan air

Cuci tangan setelah BAK dengan sabun
3

$$
15 \% \quad 12
$$

$60 \%$

3

$15 \%$

2

$10 \%$$$
2
$$$$
10 \%
$$$$
6
$$$$
30 \%
$$$$
10
$$$$
50 \%
$$$$
2
$$$$
10 \%
$$

$$
9 \quad 45 \%
$$$$
6
$$$$
30 \%
$$$$
5
$$$$
25 \%
$$

$$
15 \%
$$$$
4
$$$$
20 \%
$$$$
10
$$$$
50 \%
$$$$
3
$$

1

$$
5 \%
$$

14

$70 \%$

2

$10 \%$

\section{3}

$15 \%$

\begin{tabular}{|c|c|c|c|c|c|}
\hline & & Frequency & Percent & Valid Percent & $\begin{array}{c}\text { Cumulative } \\
\text { Percent }\end{array}$ \\
\hline \multirow[t]{6}{*}{ Valid } & Tidak pernah & 9 & 45.0 & 45.0 & 45.0 \\
\hline & $1 \mathrm{x}$ & & & & \\
\hline & $2 x$ & & & & \\
\hline & $3 x$ & 6 & 15.0 & 15.0 & 75.0 \\
\hline & & 2 & 10.0 & 10.0 & 100.0 \\
\hline & Total & 20 & 100.0 & 100.0 & \\
\hline
\end{tabular}

Tabel 4.5 Frekuensi gangguan fekal oral

Gangguancerna

Banyakgangguan

Tabel Jumlah bakteri sebelum dan sesudah mencuci tangan

\begin{tabular}{|c|c|c|}
\hline Responden & $\begin{array}{c}\text { Jumlah bakteri } \\
\text { sebelum cuci tangan }\end{array}$ & $\begin{array}{c}\text { Jumlah bakteri } \\
\text { setelah cuci tangan }\end{array}$ \\
\hline
\end{tabular}




\begin{tabular}{|c|c|c|}
\hline 1 & 3,58 & 1,23 \\
\hline 2 & 1,91 & 0,51 \\
\hline 3 & 0,99 & 0,55 \\
\hline 4 & 2,03 & 0,83 \\
\hline 5 & 0,95 & 0,35 \\
\hline 6 & 1,03 & 0,57 \\
\hline 7 & 1,27 & 0,53 \\
\hline 8 & 1,15 & 0,37 \\
\hline 9 & 1,57 & 0,61 \\
\hline 10 & 1,95 & 0,97 \\
\hline 11 & 1,05 & 0,49 \\
\hline 12 & 2,98 & 1,09 \\
\hline 13 & 2,58 & 1,35 \\
\hline 14 & 2,14 & 1,55 \\
\hline 15 & 2,74 & 1,71 \\
\hline 16 & 2,5 & 1,15 \\
\hline 17 & 2,78 & 1,33 \\
\hline 18 & 1,07 & 0,43 \\
\hline 19 & 1,11 & 0,59 \\
\hline 20 & 2,54 & 1,59 \\
\hline $\begin{array}{c}\text { Rata- } \\
\text { rata }\end{array}$ & $\frac{37.92}{20}$ & $\frac{17.8}{20} 0.89$ \\
\hline
\end{tabular}

\section{PEMBAHASAN}

Purwandari et al., (2013) menuliskankan cuci tangan seringkali diabaikan, bahkan ada masyarakat yang telah mengetahui tentang manfaat cuci tangan tetapi tidak menerapkannya. Tetapi jika sudah tertanam kebiasaan dan juga tersedianya sarana dan prasarana maka cuci tangan akan berhasil diterapkan. Apriany, (2013) mengatakan pada kenyataannya cuci tangan yang merupakan perilaku sehat belum menjadi budaya di Indonesia dan dilakukan hanya sekedarnya saja, padahal tangan merupakan pembawa utama kuman penyakit. Rabby \& Dey, 2013 menambahkan kesenjangan antara pengetahuan dan pratik cuci tangan masih berlanjut, untuk itu diperlukan inisiatif jangka panjang untuk menyadarkan masyarakat akan pentingnya mencuci tangan. 
Kemenkes RI, (2011) menuliskan kejadian diare berkaitan dengan kebersihan diri seseorang dalam penerapan cuci tangan. Dengan mencuci tangan dapat menurunkan angka kejadian diare sebesar $47 \%$. Rompas et al., (2013) menjelaskan tangan yang kotor dapat memindahkan mikroba pembawa penyakit masuk kedalam tubuh kita. Reza, Marsito, \& Saraswati (2012) mengatakan dengan menerapkan cuci tangan dengan sabun merupakan tindakan pencegahan penyakit diare.

L, et al., (2011) mengatakan resiko kontaminasi bakteri fekal pada tangan terjadi pada orang yang sering berjabat tangan, menyentuh atau mengolah tanah, dan orang yang memiliki kebersihan yang buruk.

Burton, et al., (2011) menjelaskan mencuci tangan dengan air saja dapat mengurangi munculnya bakteri pada tangan hingga $23 \%$, tetapi jika ditambah dengan sabun maka lebih efektif untuk mengangkat bakteri dari tangan. CDC, 2015 menambahkan cuci tangan harus dibawah air yang mengalir, jika mencuci tangan pada wadah maka tangan akan kembali terkontaminasi bakteri.

Girou et al, 2001 mengatakan cuci tangan dapat menurunkan jumlah kuman di tangan hingga 58\%. Rachmawati \& Triyana, (2008) menjelaskan perubahan jumlah koloni bakteri ditangan dipengaruhi oleh jenis sabun yang digunakan untuk mencuci tangan. Sabun yang digunakan dalam penelitian ini mengandung timol. Dorland, 2016 mengatakan timol merupakan asam karbolat atau benzenol yang diperoleh dari minyak timi atau dari minyak atsiri lainnya dan digunakan sebagai penetral dalam persiapan farmasi, antiseptik, antibakteri, antijamur, dan digunakan sebagai obat cacing. Braga, 2005 menambahkan timol mengandung anti mikroba yang berguna untuk melawan berbagai mikroorganisme.

Berdasarkan analisa data di atas, dapat simpulkan bahwa terdapat perbedaan yang signifikan antara jumlah bakteri sebelum dan sesudah mencuci tangan dengan sabun.
Hasil tersebut sejalan dengan hasil penelitian yang dilakukan oleh Desiyanto \& Djannah (2013) yaitu Ada perbedaan jumlah angka kuman antara kelompok kontrol (tanpa cuci tangan) dengan kelompok yang cuci tangan menggunakan sabun. Pengurangan bakteri di tangan juga dipengaruhi oleh jenis sabun atau cairan antiseptik yang digunakan.

Larson (2007) mengatakan dengan mencuci tangan dapat mengurangi jumlah koloni bakteri yang menempel pada tangan, dan mencegah penularan bakteri dan penyakit dari satu orang ke orang yang lain. CDC (2009) menuliskan metode untuk mengangkat mikroorganisme dari tangan adalah dengan mencuci tangan menggunakan sabun dan dibilas pada air yang mengalir. Yuli (2015) mengatakan cuci tangan dapat mengurangi bahkan menghilangkan kuman dan bakteri yang menempel pada tangan, jari serta kuku.

\section{DAFTAR PUSTAKA}

Apriany, D. (2013). Perbedaan perilaku mencuci tangan sebelum dan sesudah diberikan pendidikan kesehatan pada anak usia 4-5 tahun. Jurnal keperawatan soedirman, 60-66 volume 7 ,

No.22.

Center for Disease Control (2009). OPRP General information on

Hand Hygiene.[online]

http://www.cdc.gov

/nceh/vsp/cruiselines/hand hygiene general.htm. Diakses 09 Desember 2015 pukul 19.00 WIB

Center for Disease Control (2013). Wash Your Hand. 
[online]http://www.cdc. gov/features/handwashing/ diakses 19 November 2015 pukul 15.00 WIB

Braga, P. (2005). Thymol: antibacterial, antifungal and antioxidant activities. CIC Edizioni Internazionali, Roma, 263-269.

Burton, M., Cobb, E., Donachie, P., Judah, G., Curtis, V., \& Schmidt, W. (2011). The effect of handwashing with water or soap on bacterial contamination of hands. International journal of enviroment research and public health, 97-104.

Dinas Kesehatan Jawa Barat (2015) Peringatan Hari Cuci Tangan

Pakai Sabun

Sedunia.[online]:http://www.dis kes.jabarprov.go.id/index.php/p ost/read/2015/472/PeringatanHariCuci-TanganPakai.Diakses November 2015 pukul 20.00 WIB

Desiyanto, F., \& Djannah, S. (2013). Efektivitas mencuci tangan menggunakan cairan pembersih tangan sanitizer terhadap jumlah angka kuman. KESMAS, 75-82

Vol.7 No.2.

Dorland. (2016, 05 14). Thymol. Retrieved from Pubchem:

https://pubchem.ncbi.nlm.gov/c ompound/thymol\#

Girou, E, Loyeau,S, Legrand,P, Oppein,F, Buisson,CB. 2002. Efficacy of Handrubbing with an AlcoholBased Solution versus Standard Handwashing with Antiseptic Soap: randomised clinical trial. BMJ 325 : $362-5$
Health Education And Training (2013)

General Features of Faeco-

Orally Transmitted Disease

[online]

http://www.open.edu/openlearn works/mod/oucontent/view.php? $\mathrm{id}=118 \&$ section=1.7.1 diakses 5 November 2015 pukul 19.00 WIB

James, Baker, Swain (2008). Prinsipprinsip sains untuk keperawatan. Jakarta: Penerbit Erlangga.

Kemenkes RI (2011) Data dan informadi kesehatan:Situasi diare di Indonesia. [online]Available:http://www.de pkes.go.id/download.php?file=d ownload/pusdatin/buletin/buleti ndiare. pdf di unduh 26 April 2016 pukul 12.00 WIB

Larson, E. (2007). Skin Hygiene and Infection Prevention: More of the Same or Different. Columbia University School of Nursing,

1287-1294.

Nadesul, H.(2006). Sehat Itu Murah. Jakarta: Penerbit Buku Kompas

Purwandari, R., Ardiana, A., \& Wantiyah. (2013). Hubungan Antara Perilaku Mencuci Tangan dengan insiden Diare pada Anak Usia Dekolah Di Kabupaten Jember. Jurnal Keperawatan, ISSN: 2086-3071, 122130.

Rabby, E., \& Dey, N. (2013). Exploring the gap between hand washing knowledge and pratices in bangladesh: a cross-sectional 
comparative study. BMC Publice Health, 13:89, 2-7.

Purwandari, R., Ardiana, A., \& Wantiyah. (2013). Hubungan Antara Perilaku Mencuci Tangan dengan insiden Diare pada Anak Usia Dekolah Di Kabupaten Jember. Jurnal Keperawatan, ISSN: 2086-3071, 122130.

Rabby, E., \& Dey, N. (2013). Exploring the gap between hand washing knowledge and pratices in bangladesh: a cross-sectional comparative study. BMC Publice Health, 13:89, 2-7.

Rachmawati, F., \& Triyana, S. (2008). Perbandingan angka kuman pada cuci tangan dengan beberapa bahan sebagai standarisasi kerja di laboratorium mikrobiologi fakultas kedokteran universitas islam indonesia. jurnal penelitian \& pengabdian dppm.uii.ac.id, 1-13. Volume 5,

No. 1.

Reza, F., Marsito, \& Saraswati, R (2012). Efektifits penyuluhan oleh peer group dan tenaga kesehtan tentang perilaku hidup bersih sehat (PHBS)cuci tangan bersih pada siswa SD N 01 Bonosari. Jurnal ilmiah keperawtan, Volume 8,No.1.

Riskesdas (2013) Penyajian PokokPokok Hasil Riset Kesehatan

Dasar 2013.

[online]Available:http://www.de

pkes.go.id/resources/download/g

eneral/Hasil\%20Riskesdas\%202 013.pdfdi unduh 4 November 2015 pukul 19.00 WIB
Rompas, M., Tuda, J., \& Ponidjan, T. (2013). Hubungan antara perilaku cuci tangan pakai sabun dengan terjadinya diare pada anak usia sekolah di sd gmim dua kecamatan tareran. Ejournal keperawtan (e-Kp).

World Health Organization (2009). infectious diseases $A$ manual for nurses and midwives in the

WHO EuropeanRegion.

[online] http:/

/www.euro.who.int/ data/assets/pdf file/0013/10231 6/e79822.pdf diunduh 02 Oktober 2015 pukul 14.00 WIB

Yuli (2015).Manfaat Mencuci Tangan

Dengan Air Bersih dan

Sabun.[online] http://manfaat.co.id/manfaatmencucitangan-dengan-airbersih-dan-sabun. diakses 11 Oktober 2015 pukul 20.00 WIB 